\title{
Impact of COVID-19 on Remittance Inflows to Samoa
}

\author{
Hong Chen', Shamal S Chand ${ }^{2}$, Baljeet singh ${ }^{3}$ (1) ${ }^{a}$ \\ ${ }^{1}$ Fujian University of Technology, China, ${ }^{2}$ The University of the South Pacific, Fiji, ${ }^{3}$ School of Economics, The University of the South Pacific, Fiji \\ Keywords: samoa, covid-19, remittances \\ 10.46557/001c.17894
}

\section{Asian Economics Letters}

This paper examines the impact of the COVID-19 pandemic on remittance inflows to Samoa. The study finds that COVID-19 has led to increased remittance inflows to Samoa from Australia and New Zealand; however, remittances from the United States have declined.

\section{Introduction}

The COVID-19 pandemic, which has affected many countries since January 2020, has created large-scale contractions of economies globally (International Monetary Fund, 2020). The more the pandemic affects economic growth and employment prospects in developed countries, the greater will be the effects on low income, developing countries. An immediate loss is predicted to be through reduced remittance inflows from developed countries (Sayeh \& Chami, 2020). World Bank (2020) projects a 20 percent decline in remittances and a loss of $\$ 445$ billion in remittances to low and middle-income countries due to loss of income and employment of migrant workers. Several studies note a significant reduction in remittances due to COVID-19 in Africa (Bisong et al., 2020), the Philippines (Ang \& Opiniano, 2020; Murakami et al., 2020) and Bangladesh (Das, 2020). A significant loss of remittances will have a profound impact on household's social protection net and progression of sustainable development goals. This paper investigates the effect of COVID-19 on remittance inflows to Samoa from three major remittance sending countries, namely Australia, New Zealand, and the United States. The case of Samoa is interesting since remittances represent around 20 percent of its GDP and it is the sixth largest remittance receiving country (Gaillard \& Friesen, 2015; World Trade Organization, 2019). Moreover, remittances reached around 40 percent of all households in Samoa, making up a significant portion of family income (AusAID, 2012). Since remittances in Samoa are a major contributor to economic output and household income, the effect of external shocks, such as the COVID-19 pandemic, could have severe implications. Previously, economic and disaster shocks had mixed effects on Samoa's remittance inflows. Remittances were 3.6 times higher during the 2009 tsunami compared to a normal year (Le De et al., 2016) while remittances declined during the 2009 global financial crisis as a result of laid-off Samoan migrants (AusAID, 2012).

In this paper, we examine the determinants of remittance inflows to Samoa. In light of the discussion above, which points towards a significant decline in remittances due to the COVID-19 pandemic, our hypothesis is that COVID-19 has negatively impacted remittance inflows to Samoa. We test this hypothesis using a cointegration and vector error correction framework. We find that COVID-19 has led to increased remittances to Samoa from Australian and New Zealand, while remittances from the United States have declined. This finding contributes to the scarce literature (Ang \& Opiniano, 2020; Bisong et al., 2020; Das, 2020; Murakami et al., 2020) on the effects of COVID-19 on remittances. By studying a country, Samoa, which is the $5^{\text {th }}$ largest recipient of remittance, we set the framework and motivation for more analysis building on our work.

The rest of the paper is structured as follows: Section II provides the methodology and data. Section III discusses the empirical findings and Section IV concludes and provides policy implications.

\section{Methodology, Data, and Preliminary Observations}

The effects of the COVID-19 pandemic on remittance inflows are tested within a vector error correction (VECM) model: ${ }^{1}$

$$
\Delta Y_{t}=\alpha+\emptyset\left(\text { lnrem }_{t-1}-\sum \gamma X_{t-1}\right)+\sum_{j=1}^{p-1} \beta_{j}^{*} \Delta Y_{t-j}+\varepsilon_{t}
$$

where $Y_{t}$ is each variable covered in the model, including lnrem $_{t}$ and a vector of variables $X_{t} ; \Delta Y_{t}$ is the first difference of each variable; lnrem $_{t}$ is the natural logarithm of remittances from either Australia, New Zealand or the United States to Samoa (US\$, current prices); and $\varepsilon_{t}$ is a classical error term. The $\emptyset, \gamma, \alpha$ and $\beta$ are parameters to be estimated. The parameter, $\emptyset$, captures the error correcting term (ECT ) and measures the speed at which the model returns to equilibrium after a shock. The parameter, $\gamma$, captures the long-run equilibrium relationship between Inrem $_{t}$ and $X_{t}$. The parameter, $\alpha$, captures the constant term in the shortrun relationships, and $\beta$ captures short-run dynamic effects of changes in all variables stated in Equation (1).

The vector $X_{t}$ includes the COVID-19 pandemic variables of interest, represented by three indicators. (1) a dummy variable, denoted by $d_{u m}$, with value 1 for months March 2020 onwards, and 0 otherwise. This is based on the period when deaths from the pandemic began. The starting month when first deaths from the pandemic were recorded is the same in Australia, New Zealand and the United States. (2) the number of confirmed COVID-19 cases per million population, denoted by casespm . $_{t}$ (3) the number of deaths caused by COVID-19 per million population, denoted by deathspm .

\footnotetext{
a Corresponding author: singh_bl@usp.ac.fj

1 This study runs the VEC regressions individually for Australia, New Zealand and the United States using time series data.
} 


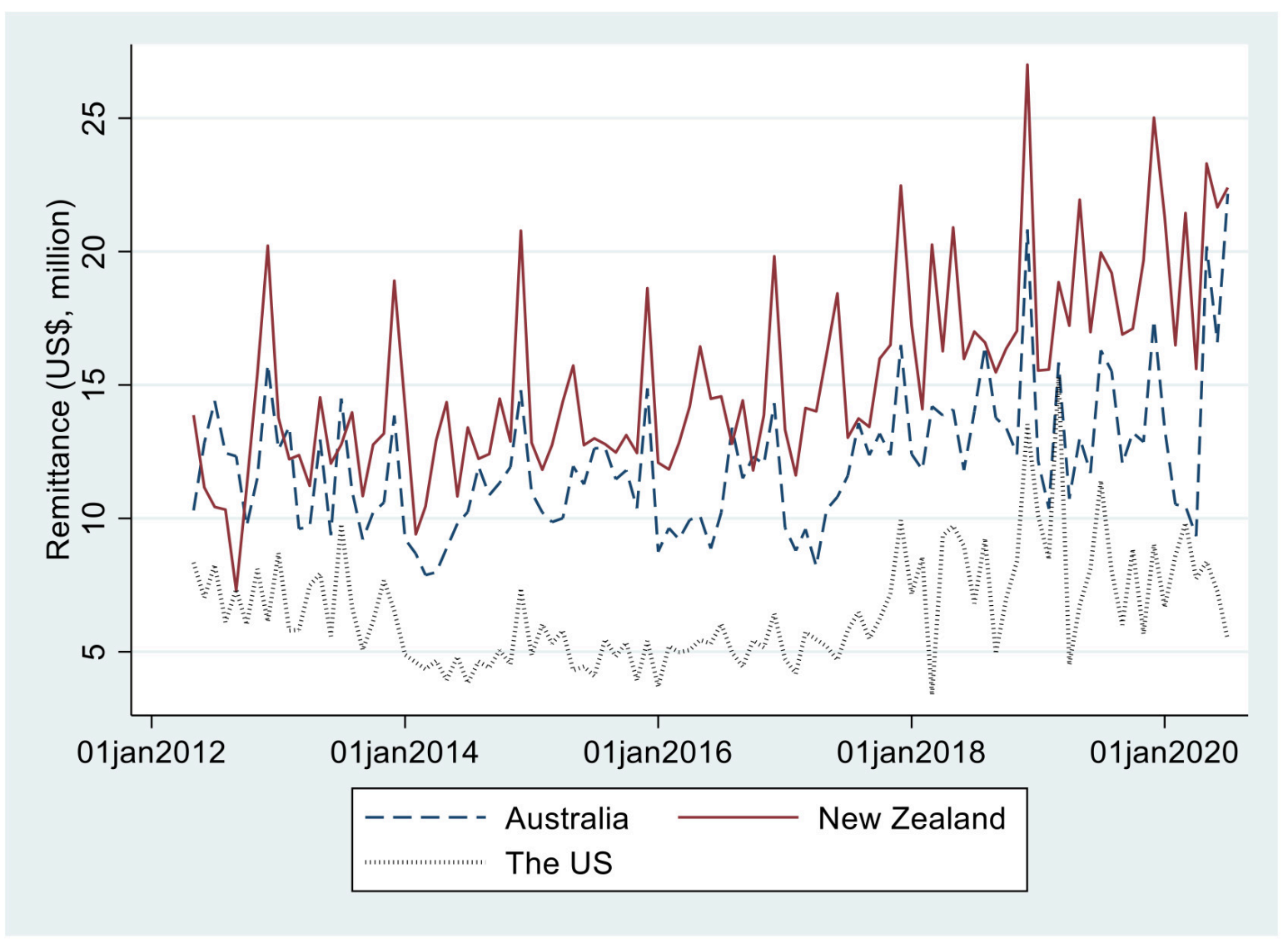

Figure 1: Remittance Inflows to Samoa from major source countries, March 2012 to July 2020

The figure plots the trend in remittance inflows to Samoa from Australia, New Zealand and the United States.

The control variables in the vector $X_{t}$ include factors of the following dimensions: $:^{2}(1)$ economic performance of remittance originating country, represented either by unemployment rate in percentage (denoted by $u n_{t}$ ) or by the industrial production index (denoted by $i p_{t}$ ); (2) exchange rate, represented by Samoan Tala per origin country's currency (denoted by $e x_{t}$ ); and (3) the cost of sending remittance in the United States dollars (natural logarithm, denoted by $\ln \cos t_{t}$ ).

In this study, we utilize monthly data from May 2012 to July 2020. A prior look at remittance inflows trend in Figure 1 shows remittances from Australia and New Zealand have an increasing trend from January 2020 while it declined for the United States. We obtained the remittances inflow, monthly cost and exchange rate indicators from the Central Bank of Samoa while the unemployment rate, interbank rate and industrial production indexes $(I P I)$ are sourced from the Federal Reserve Economic Data. The IPI was transformed from quarterly to monthly frequency through using cubic spline interpolation. The number of COVID-19 cases and deaths is obtained from the World Health Organization.

The Clemente-Montanes-Reyes unit root test developed by (1998) and the Narayan and Popp unit root test developed by Narayan \& Popp (2010) is employed to test for a unit root in the presence of double structural breaks. Test statistics reveal that all variables included in the current analysis are integrated of order one. Furthermore, the Gregory-Hansen (1996) test for cointegration with potential regime shifts is employed in this study. Three statistical tests, namely the augmented Dickey Fuller test (the ADF), the $Z_{t}$ test, and the $Z_{a}$ test, provide strong evidence that there exists cointegrating relationships for the variables presented in Equation (1) for Australia, New Zealand and the United States.

\footnotetext{
2 Another control variable, which is available at the monthly frequency and relevant according to the literature on the determinants of remittances considered in this study is interbank rate. However, due to its high correlation with the two economic performance indicators, industry production index and unemployment, interbank rate is excluded from the regressions.
} 
Table 1: Effects of COVID-19 pandemic on remittance inflows to Samoa

\begin{tabular}{|c|c|c|c|c|c|c|c|c|c|}
\hline \multirow{2}{*}{$\begin{array}{l}\text { Country of origin } \\
\text { Regression no.: }\end{array}$} & \multicolumn{3}{|c|}{ Australia } & \multicolumn{3}{|c|}{ New Zealand } & \multicolumn{3}{|c|}{ The US } \\
\hline & (1) & (2) & (3) & (4) & (5) & (6) & (7) & (8) & (9) \\
\hline \multicolumn{10}{|l|}{ Long-run effects } \\
\hline$e x_{t}$ & $\begin{array}{l}1.24^{* * *} \\
(2.67)\end{array}$ & $\begin{array}{c}0.60 \\
(0.87)\end{array}$ & $\begin{array}{l}1.11^{* *} \\
(2.21)\end{array}$ & $\begin{array}{l}0.004 \\
(0.00)\end{array}$ & $\begin{array}{c}0.26 \\
(0.30)\end{array}$ & $\begin{array}{c}0.55 \\
(0.57)\end{array}$ & $\begin{array}{c}-4.16 \\
(-1.30)\end{array}$ & $\begin{array}{c}-20.8 \\
(-0.08)\end{array}$ & $\begin{array}{l}-5.16^{*} \\
(-1.82)\end{array}$ \\
\hline lncost $_{t}$ & $\begin{array}{c}-0.01 \\
(-0.09)\end{array}$ & $\begin{array}{c}0.11 \\
(0.69)\end{array}$ & $\begin{array}{c}-0.05 \\
(-0.46)\end{array}$ & $\begin{array}{l}-0.23^{*} \\
(-1.91)\end{array}$ & $\begin{array}{l}-0.22^{*} \\
(-1.92)\end{array}$ & $\begin{array}{l}-0.22^{*} \\
(-1.68)\end{array}$ & $\begin{array}{l}-0.92^{*} \\
(-1.77)\end{array}$ & $\begin{array}{l}28.10 \\
(0.65)\end{array}$ & $\begin{array}{l}-1.26 * * \\
(-2.80)\end{array}$ \\
\hline$u n_{t}$ & $\begin{array}{l}-0.27^{* * *} \\
(-6.21)\end{array}$ & $\begin{array}{l}-0.28^{* * *} \\
(-4.32)\end{array}$ & $\begin{array}{l}-0.26 * * \\
(-5.40)\end{array}$ & $\begin{array}{l}-0.23^{* * *} \\
(-8.58)\end{array}$ & $\begin{array}{l}-0.22^{* * *} \\
(-8.35)\end{array}$ & $\begin{array}{l}-0.20^{* * *} \\
(-6.999)\end{array}$ & & & \\
\hline$i p_{t}$ & & & & & & & $\begin{array}{c}3.55 \\
(1.45)\end{array}$ & $\begin{array}{c}143.00 \\
(0.69)\end{array}$ & $\begin{array}{c}1.48 \\
(0.69)\end{array}$ \\
\hline $\operatorname{dum}_{t}$ & $\begin{array}{l}1.05^{* * *} \\
(5.90)\end{array}$ & & & $\begin{array}{c}0.00 \\
(0.00)\end{array}$ & & & $\begin{array}{l}-2.29^{* * * *} \\
(-2.77)\end{array}$ & & \\
\hline casespm $_{t}$ & & $\begin{array}{l}0.01^{* * * *} \\
(6.14)\end{array}$ & & & $\begin{array}{l}0.00^{* *} \\
(2.32)\end{array}$ & & & $\begin{array}{c}-78^{* * *} \\
(-24.64)\end{array}$ & \\
\hline deathspm $_{t}$ & & & $\begin{array}{l}1.04^{* * *} \\
(8.45)\end{array}$ & & & $\begin{array}{l}0.23^{* * *} \\
(3.59)\end{array}$ & & & $\begin{array}{l}0.003 \\
(0.76)\end{array}$ \\
\hline$\left(\right.$ lnrem $\left._{t-1}-\sum \gamma X_{t-1}\right)$ & $\begin{array}{l}-0.58^{* * *} \\
(-4.71)\end{array}$ & $\begin{array}{l}-0.43^{* * *} \\
(-5.27)\end{array}$ & $\begin{array}{l}-0.51^{* * *} \\
(-6.20)\end{array}$ & $\begin{array}{l}-0.98^{* * *} \\
(-5.87)\end{array}$ & $\begin{array}{c}-1.00^{* * *} \\
(-5.91)\end{array}$ & $\begin{array}{l}-0.91^{* * *} \\
(-5.75)\end{array}$ & $\begin{array}{c}-0.26^{* * *} \\
(-2.74)\end{array}$ & $-0.002(-1.01)$ & $\begin{array}{l}-33^{* * *} \\
(-2.86)\end{array}$ \\
\hline \multicolumn{10}{|l|}{ Short-run effects } \\
\hline$\Delta d u m_{t-1}$ & $\begin{array}{l}-0.83^{* * *} \\
(-3.43)\end{array}$ & & & $\begin{array}{c}-0.13 \\
(-0.72)\end{array}$ & & & $\begin{array}{c}0.77 \\
(1.59)\end{array}$ & & \\
\hline$\Delta d u m_{t-2}$ & $\begin{array}{c}0.17 \\
(0.74)\end{array}$ & & & $\begin{array}{c}0.17 \\
(1.00)\end{array}$ & & & $\begin{array}{c}1.12 \\
(1.36)\end{array}$ & & \\
\hline$\Delta$ casespm $_{t-1}$ & & $\begin{array}{c}-0.006^{* * *} \\
(-4.98)\end{array}$ & & & $\begin{array}{c}-0.002^{* *} \\
(-2.19)\end{array}$ & & & $0.000(0.79)$ & \\
\hline$\Delta$ casespm $_{t-2}$ & & $\begin{array}{c}-.001 \\
(-1.57)\end{array}$ & & & $\begin{array}{c}-.001 \\
(-0.95)\end{array}$ & & & $\begin{array}{l}.0007^{*} \\
(1.74)\end{array}$ & \\
\hline$\Delta$ deathspm $m_{t-1}$ & & & $\begin{array}{l}-0.32^{* * *} \\
(-3.38)\end{array}$ & & & $\begin{array}{l}-0.12^{* * *} \\
(-2.53)\end{array}$ & & & $\begin{array}{l}0.003 \\
(0.86)\end{array}$ \\
\hline$\Delta$ deathspm $t_{t-2}$ & & & $\begin{array}{c}-0.20^{* * *} \\
(-2.78)\end{array}$ & & & $\begin{array}{l}-0.08^{*} \\
(-1.88)\end{array}$ & & & $\begin{array}{l}0.01^{* *} \\
(2.23)\end{array}$ \\
\hline \multicolumn{10}{|l|}{ Performance of regressions } \\
\hline Coint. eq.: chi2 [p-value] & $\begin{array}{l}78.94 \\
{[0.00]}\end{array}$ & $\begin{array}{l}55.89 \\
{[0.00]}\end{array}$ & $\begin{array}{l}117.4 \\
{[0.00]}\end{array}$ & $\begin{array}{l}126.0 \\
{[0.00]}\end{array}$ & $\begin{array}{l}149.1 \\
{[0.00]}\end{array}$ & $\begin{array}{l}130.1 \\
{[0.00]}\end{array}$ & $\begin{array}{l}25.49 \\
{[0.00]}\end{array}$ & $\begin{array}{c}803 \\
{[0.00]}\end{array}$ & $\begin{array}{c}21.3 \\
{[0.00]}\end{array}$ \\
\hline Dynamic equation: R-squares & 0.60 & 0.56 & 0.58 & 0.52 & 0.51 & 0.50 & 0.43 & 0.40 & 0.45 \\
\hline
\end{tabular}

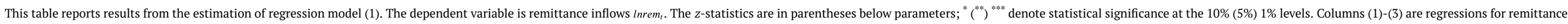
inflows from Australia to Samoa, columns (4)-(6) are regressions for remittance inflows from New Zealand to Samoa, and columns (7)-(9) are regressions for remittance inflows from the United States to Samoa. 


\section{Empirical Results}

The VECM regression results are summarized in Table $1 .^{3}$ The long-run equilibrium relationships are reported in the top panel of Table 1. For short-run dynamic relationships, to conserve space, only dynamic effects of each pandemic indicator on $\Delta$ lnrem $_{t}$ are reported in the bottom panel of Table 1. As the lagged residual $\left(\right.$ Inrem $\left._{t-1}-\sum \gamma X_{t-1}\right)$ has a negative and statistically significant sign in all regressions, except for column (8), there is strong evidence of a longrun equilibrium causal effects of control variables and the COVID-19 pandemic on remittances to Samoa. Exchange rate plays a significant role in promoting remittance inflows from Australia to Samoa only. The cost of sending remittances negatively affects remittance inflows from New Zealand and the United States, which does not hold for remittances from Australia. Economic performance is found to be contributing positively to remittance inflows to Samoa, with the evidence of a negative association between unemployment rate and remittance inflow from Australia and New Zealand and a positive association between industrial production index in the United States and remittance inflows to Samoa. There is strong evidence that the COVID-19 pandemic effects in Australia and New Zealand have contributed to more remittance flows to Samoa from these two countries, while, it has negatively influenced remittance inflows from the United States. The short-term effects of COVID-19 on remittances to Samoa are country sensitive. It is found that the pandemic leads to short-term reduction of remittances from Australia and New Zealand to Samoa.

\section{Conclusion}

This study examined the impact of COVID-19 on Samoa's remittance inflows from Australia, New Zealand and the United States. The study finds strong evidence that the pandemic positively affects long-term remittance inflows to Samoa from Australia and New Zealand, which contradicts prior studies, such as Murakami et al. (2020) that concluded a negative relationship. On the other hand, remittances to Samoa from the United States is negatively impacted by the pandemic. Cultural collectivism and strong family links in Samoa could explain the higher remittance inflows to support the home-based family members. Also, the effects of the pandemic have been far more serious in the United States in terms of cases and deaths compared to Australia and New Zealand. Given the strong cultural and social links between the Pacific Island countries and Australia and New Zealand, the remittance support for Pacific Islanders is likely to stay strong during the pandemic.

Submitted: October 19, 2020 AEDT, Accepted: October 28, 2020 AEDT

This is an open-access article distributed under the terms of the Creative Commons Attribution 4.0 International License (CCBY-SA-4.0). View this license's legal deed at https://creativecommons.org/licenses/by-sa/4.0 and legal code at https://creativecommons.org/licenses/by-sa/4.0/legalcode for more information.

3 To save space, only the ECM's parameters and short-run effects of COVID-19 variables in individual regressions are reported. 


\section{REFERENCES}

Ang, A. P., \& Opiniano, J. (2020). Possible Economic Impacts of Falling Oil Prices, the Pandemic, and the Looming Global Recession onto Overseas Filipinos and their Remittances. Working Paper Series, 2020-05, 1-10.

AusAID. (2012). AusAID Pacific social protection series: Poverty, vulnerability and social protection in the Pacific. https://www.dfat.gov.au/sites/default/file s/samoa-case-study.pdf

Bisong, A., Ahairwe, P., \& Njoroge, E. (2020). The impact of COVID-19 on remittances for development in Africa. https://ecdpm.org/wp-content/uploads/Imp act-COVID-19-remittances-development-Africa-ECD PM-discussion-paper-269-May-2020.pdf

Clemente, J., Montañés, A., \& Reyes, M. (1998). Testing for a unit root in variables with a double change in the mean. Economics Letters, 59(2), 175-182. https://doi.org/10.1016/s0165-1765(98)000 52-4

Das, B. C. (2020). The impact of COVID-19 Pandemic on the Inflow of Remittances: Perspective of Bangladesh. SSRN 3632881.

Gaillard, L., \& Friesen, W. (2015). Remittances and disaster: Policy implications for disaster risk management. Migration, Environment and Climate Change: Policy Brief Series, 1(2), 1-9.

International Monetary Fund. (2020). World Economic Outlook Update, June 2020. https://www.im f.org/en/Publications/WEO/Issues/2020/06/24/WEOU pdateJune2020
Le De, L., Gaillard, J. C., Friesen, W., Pupualii, M., Brown, C., \& Aupito, A. (2016). Our family comes first: Migrants' perspectives on remittances in disaster. Migration and Development, 5(1), 130-148. https://doi.org/10.1080/21632324.2015.1017971

Murakami, E., Shimizutani, S., \& Yamada, E. (2020). Projection of the Effects of the COVID-19 Pandemic on the Welfare of Remittance-Dependent Households in the Philippines. Economics of Disasters and Climate Change. https://doi.org/10.1007/s41885-02 0-00078-9

Narayan, P. K., \& Popp, S. (2010). A new unit root test with two structural breaks in level and slope at unknown time. Journal of Applied Statistics, 37(9), 1425-1438. https://doi.org/10.1080/02664760903039 $\underline{883}$

Sayeh, A., \& Chami, R. (2020). Lifelines in Danger: The COVID-19 pandemic threatens to dry up a vital source of income for poor and fragile countries. Finance \& Development, 57(2), 16-19.

World Bank. (2020). World Bank Predicts Sharpest Decline of Remittances in Recent History [Press release]. https://www.worldbank.org/en/news/press-r elease/2020/04/22/world-bank-predicts-sharpest-decl ine-of-remittances-in-recent-history

World Trade Organization. (2019). Trade Policy Review. https://www.wto.org/english/tratop_e/tpr_e/g 386 e.pdf 